\title{
Durable Superhydrophobic Wood via a One-step Immersion in Composite Silane Solution
}

\author{
Junfei Ou ${ }^{*}$, Guoqing Zhao ${ }^{a}$, Fajun Wang ${ }^{\mathrm{a}}$, Wen $\mathrm{Li}^{\mathrm{a}}$, Sheng Lei ${ }^{\mathrm{a}}$, Xinzuo Fang ${ }^{\mathrm{a}}$, Abdul Rahim \\ Siddiqui ${ }^{\mathrm{a}}$, Yongmei Xia ${ }^{\mathrm{a}}$, and Alidad Amirfazli ${ }^{*}$
}

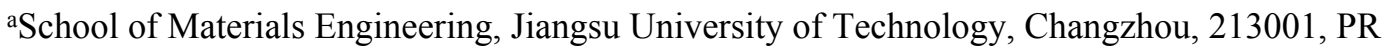
China

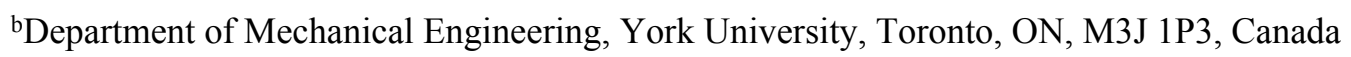

${ }^{*}$ To whom correspondence should be addressed.

Email: oujunfei_1982@163.com (JF Ou) or alidad2@yorku.ca (A Amirfazli)

Table S1. The reported superhydrophobic wood fabricated via different methods and the durability.

Table S2. Contact angle of water droplet on different substrates treated by MTMS.

Figure S1. Possible bonding mechanism for hexadecyltrimethoxysilane (HDTMS) and HDTMS / methyltrimethoxysilane (MTMS) to the wood.

Figure S2. The deconvoluted C1s core-level x-ray photoelectron spectrum for the superhydrophobic Balsawood after UV irradiation for $200 \mathrm{hrs}$.

Movie S1. Tape-peeling resistance of the coating on the Balsawood.

Movie S2. Knife-cutting resistance of the coating on the Balsawood.

Movie S3. Abrading resistance of the coating on the Balsawood. The load is $5 \mathrm{kPa}$. 
Table S1. The reported superhydrophobic wood fabricated via different methods and the durability

\begin{tabular}{|c|c|c|c|}
\hline Fabrication and Wettability & Surface features & Durability & $\operatorname{Ref}^{\S}$ \\
\hline $\begin{array}{c}\text { Fluorinated } \mathrm{SiO}_{2} \mathrm{NPs} \text { by } \\
\text { spraying; } \mathrm{CA}=168^{\circ}, \mathrm{SA}=3-5^{\circ}\end{array}$ & & $\begin{array}{c}\text { CA remained above } 160^{\circ} \text { after } 10 \text { days in } \\
\text { water or ethylene glycol }\end{array}$ & 5 \\
\hline $\begin{array}{l}\mathrm{ZnO} \text { by hydrothermal process } \\
\text { followed by modified with } \\
\text { stearic acid; } \mathrm{CA}=151^{\circ}, \mathrm{SA}<5^{\circ}\end{array}$ & & NA & 6 \\
\hline $\begin{array}{l}\text { Immersion in aqueous solution } \\
\text { of potassium methyl siliconate } \\
\text { and } \mathrm{CO}_{2} \text {, followed by } \\
\text { condensation at } 120^{\circ} \mathrm{C} \text {; } \\
\qquad \mathrm{CA}=153^{\circ}, \mathrm{SA}=4.6^{\circ}\end{array}$ & & $\begin{array}{l}\text { CA decreased to approx. } 78^{\circ}(\mathrm{pH}=12) \text { or } \\
121^{\circ}(\mathrm{pH}=2) \text { after } 12 \mathrm{hrs} \text { in aqueous } \\
\text { solution }\end{array}$ & 7 \\
\hline $\begin{array}{l}\mathrm{SiO}_{2} \mathrm{NPs} \text { by a sol-gel process } \\
\text { followed by chemical vapor } \\
\text { deposited with } \mathrm{FAS} \mathrm{S}^{*} \\
\mathrm{CA}=164^{\circ}, \mathrm{SA}<3^{\circ}\end{array}$ & & NA & 8 \\
\hline $\begin{array}{l}\mathrm{PVA} / \mathrm{SiO}_{2} \text { composite coating } \\
\text { on wood by drop-coating, } \\
\text { followed by modified with } \\
\text { octadecyltrichlorosilane; } \\
\mathrm{CA}=159^{\circ}, \mathrm{SA}=4^{\circ}\end{array}$ & & $\begin{array}{l}\text { CA decreased to } 152^{\circ} \text { and } \mathrm{SA} \text { increased to } \\
72^{\circ} \text { after abrasion in } 200 \mathrm{~cm} \text { length at } 5 \\
\mathrm{kPa} \text { pressure against filter paper }\end{array}$ & 9 \\
\hline $\begin{array}{l}\text { Hydrothermal treatment with } \\
\text { tetrabutyl titanate and } \\
\text { vinyltriethoxysilane; } \\
\mathrm{CA}=153^{\circ},{ }^{*} \mathrm{CAH}=4^{\circ}\end{array}$ & & NA & 10 \\
\hline $\begin{array}{l}\text { Copper was electroless plated } \\
\text { on wood, followed by } \\
\text { passivation with FAS } \\
\text { CA }=160^{\circ}, \mathrm{SA}=3^{\circ}\end{array}$ & & $\begin{array}{l}\mathrm{CA} \text { and SA varied to } 152^{\circ} \text { and } 16^{\circ} \text {, } \\
\text { respectively, after } 4 \text { times of abrasion } \\
\text { against abrasive paper }(1000 \#) \text { under a load } \\
\text { of } 327 \mathrm{~Pa} \text {; } 4 \mathrm{~B} \text { adhesion according to the } \\
\text { ASTM D3359 standard }\end{array}$ & 11 \\
\hline $\begin{array}{c}\text { PDMS and stearic acid } \\
\text { modified nano- } \mathrm{Al}(\mathrm{OH})_{3} \text { were } \\
\text { successively deposited onto the } \\
\text { lignocellulose composites; } \\
\mathrm{CA}=156^{\circ}, \mathrm{SA}<5^{\circ}\end{array}$ & & $\begin{array}{l}\text { CA unchanged, SA increased to approx. } 10^{\circ} \\
\text { after } 400 \mathrm{~cm} \text { abrasion against abrasive } \\
\text { paper }(1500 \#) \text { under } 5 \mathrm{kPa} \text {; CA below } 150^{\circ} \\
\text { and } \mathrm{SA} \text { above } 15^{\circ} \text { after } 8 \mathrm{hrs} \text { in aqueous } \\
\text { solution at pH } 1 \text { and pH } 13\end{array}$ & 12 \\
\hline
\end{tabular}




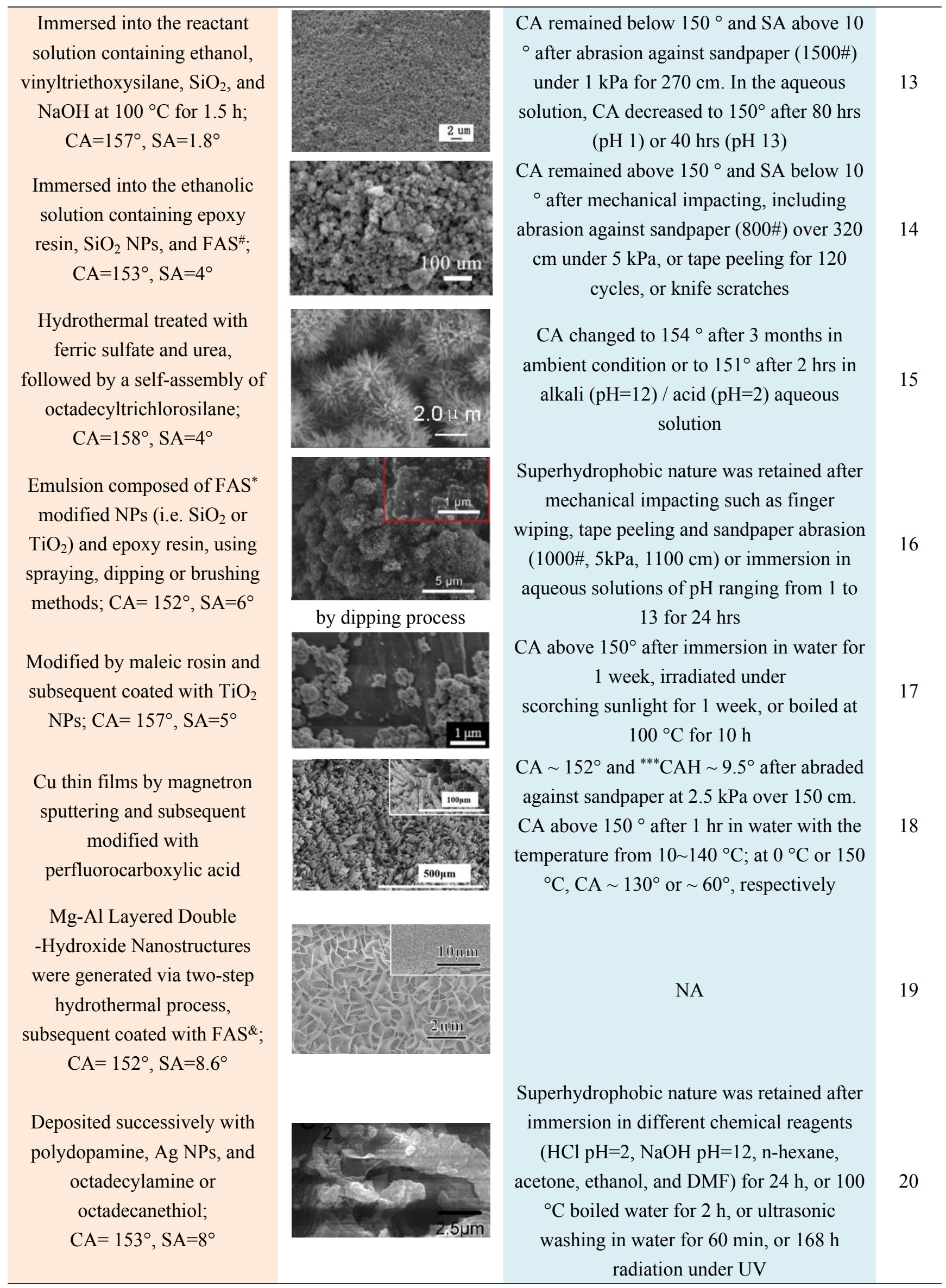

${ }^{*} \mathrm{FAS}=1 \mathrm{H}, 1 \mathrm{H}, 2 \mathrm{H}, 2 \mathrm{H}$ - perfluorooctyltriethoxysilane

$*_{\mathrm{CAH}=\text { contact angle hysteresis }}$

${ }^{\#} \mathrm{FAS}=1 \mathrm{H}, 1 \mathrm{H}, 2 \mathrm{H}, 2 \mathrm{H}$ - perfluorooctyltrimethoxysilane 
${ }^{\&} \mathrm{FAS}=1 \mathrm{H}, 1 \mathrm{H}, 2 \mathrm{H}, 2 \mathrm{H}$ - perfluorodecyltrimethoxysilane

$\S$ Reference number is the same as shown in the main text of this submission

Table S2. Contact angle of water droplet on different substrates treated by MTMS

\begin{tabular}{|c|c|c|c|}
\hline Substrate & Treating details & CA (deg) & $\operatorname{Ref}^{\S}$ \\
\hline Mg alloy & $\begin{array}{l}\text { The rough substrate was immersed into the mixture of MTMS, } \\
\text { ethanol and water ( } 3: 10: 20 \text {, volume ratio) at } 323 \mathrm{~K} \text { for } 2 \mathrm{~h} \\
\text { followed by heating at } 120^{\circ} \mathrm{C} \text { for } 2 \mathrm{~h}\end{array}$ & 152 & 25 \\
\hline $\begin{array}{l}\text { Polyester } \\
\text { fabric }\end{array}$ & $\begin{array}{l}\text { The fabric was immersed into the acid- or base-catalyzed } \\
\text { MTMS coating solution for } 0.5 \text { to } 2 \mathrm{~h}\end{array}$ & $140 \sim 155$ & 26 \\
\hline $\begin{array}{l}\text { Melamin } \\
\text { e foam }\end{array}$ & $\begin{array}{l}\text { Two open glass vessels containing } 2 \mathrm{~mL} \text { of MTMS and } \\
\text { aqueous ammonia, respectively, were put into the glass } \\
\text { desiccator and maintained at } 100^{\circ} \mathrm{C} \text { for } 5 \mathrm{~h}\end{array}$ & $\sim 148$ & 27 \\
\hline $\begin{array}{l}\text { Stainless } \\
\text { steel } \\
\text { plate }\end{array}$ & $\begin{array}{l}\text { MTMS was mixed with } 0.1 \mathrm{M} \mathrm{HCl} \text { in a } 4: 1 \text { ratio and sonicated } \\
\text { in an ice-water bath for } 5 \text { min to induce hydrolysis. Substrate } \\
\text { was immersed therein for } 2 \text { min followed by air-drying under } \\
\text { ambient conditions for } 1 \mathrm{~h}\end{array}$ & $<10$ & 28 \\
\hline $\begin{array}{l}\text { Si wafer } \\
\text { /wood }\end{array}$ & $\begin{array}{l}\text { The cleaned substrates were immersed into a mixture of } \\
\text { MTMS }(150 \mu \mathrm{L}), \mathrm{H}_{2} \mathrm{O}(20 \mathrm{~mL}) \text {, and } \mathrm{C} 2 \mathrm{H} 5 \mathrm{OH}(10 \mathrm{~mL}) \text { for } 6 \\
\text { hrs. The silicon wafer was transferred into ethanol under } \\
\text { ultrasonication for } 5 \text { min and air dried. The wood was taken } \\
\text { out and dried at } 120^{\circ} \mathrm{C} \text { for } 30 \mathrm{~min}\end{array}$ & $\begin{array}{c}66(\mathrm{Si}) \\
\sim 0 \text { (wood) }\end{array}$ & work \\
\hline
\end{tabular}

$\S$ Reference number is the same as shown in the main text of this submission 


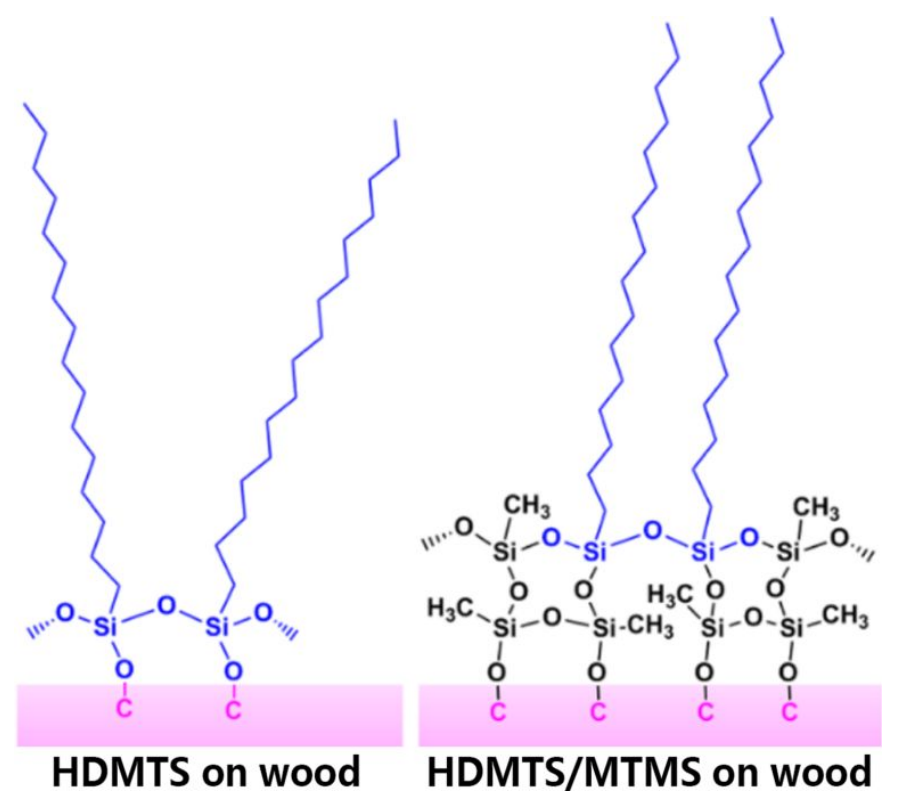

Figure S1. Possible bonding mechanism for hexadecyltrimethoxysilane (HDTMS) and HDTMS / methyltrimethoxysilane (MTMS) to the wood.

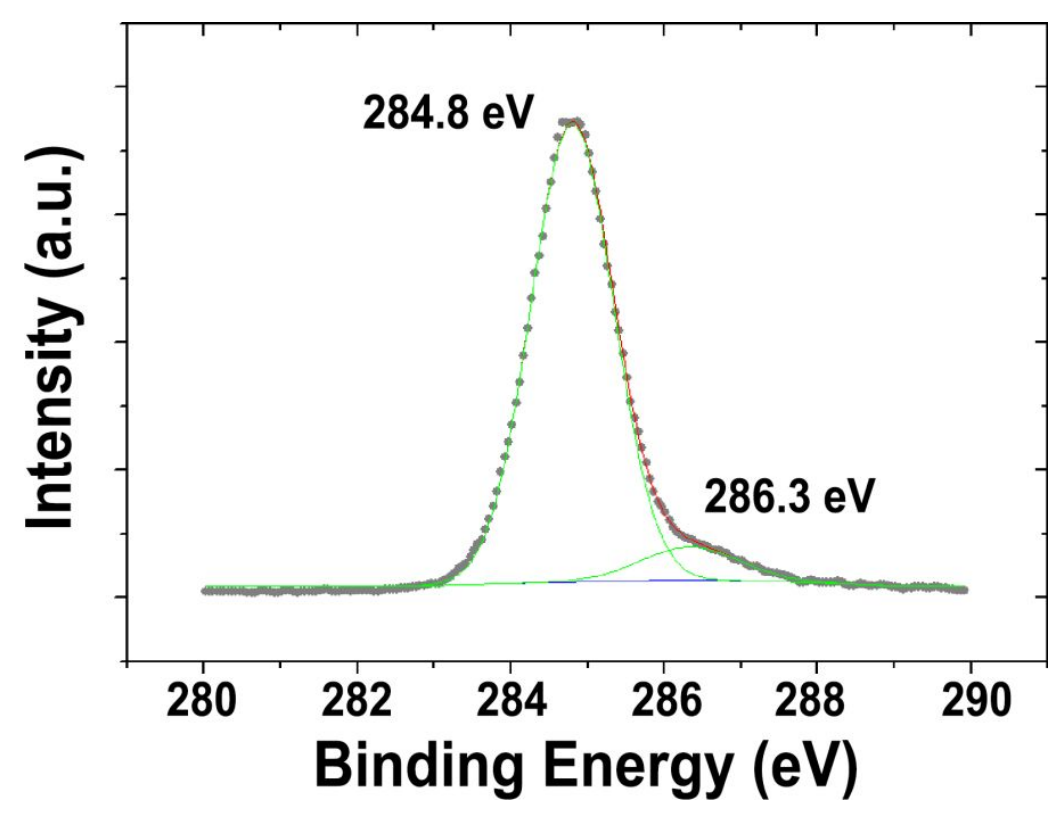

Figure S2. The deconvoluted C1s core-level x-ray photoelectron spectrum for the superhydrophobic Balsawood after UV irradiation for $200 \mathrm{hrs}$ 